\title{
Maximizing Toxicity of Certain Insecticides Against Tribolium castaneum (Herbst)
}

\author{
A.H. Mansee ${ }^{1 \star}$ and M.R. Montasser ${ }^{2}$ \\ ${ }^{1}$ Department of Pesticide Chemistry, Faculty of Agriculture \\ (El-Shatby), University of Alexandria, Egypt. \\ ${ }^{2}$ Central Lab of Pesticide, Agricultural Research Center \\ (Sabahia), Alexandria, Egypt.
}

رفع السمية الأبادية لبعض المبيدات الحشرية ضد خنفساء الدقيق الحمراء

أيمن منسي ومنال منتصر المبيدات الحشرية ضدر

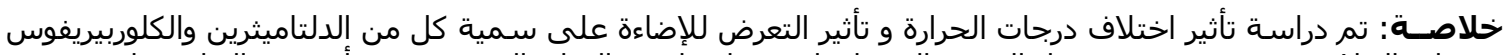

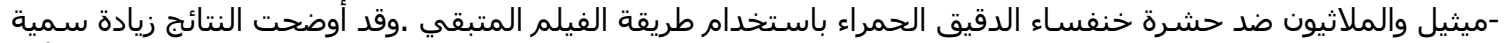

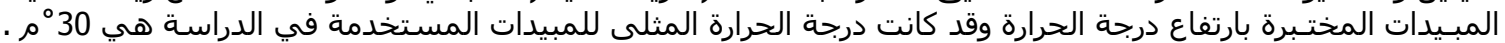

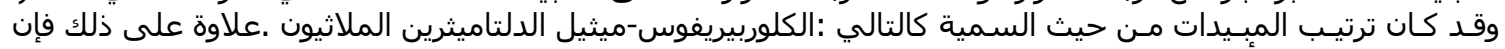

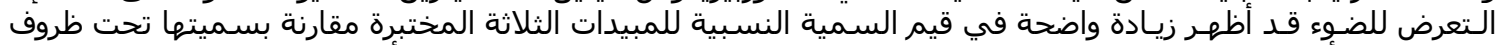

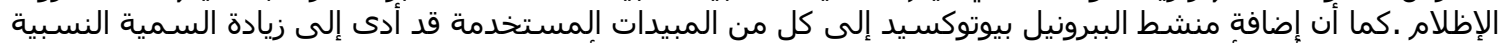

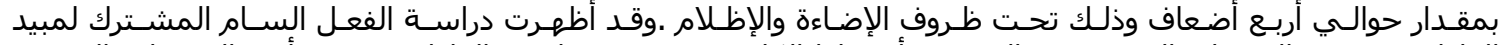

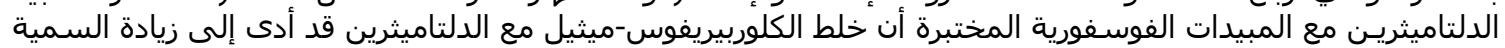

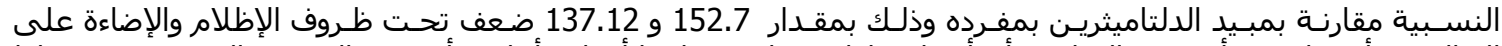

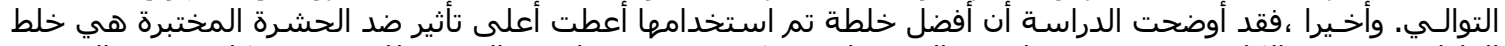

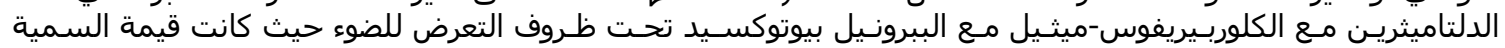

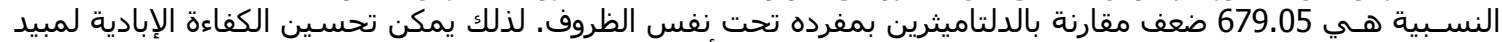

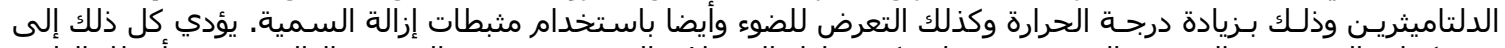

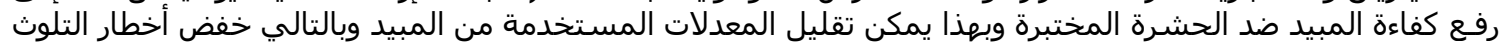
البيئي وكذلك خفاة خفض صفة المقاومة للحشرة المشرة للمبيدات.
\end{abstract}

\begin{abstract}
Effects of temperature and light exposure on the toxicity of deltamethrin, chlorpyrifos-methyl, and malathion against Tribolium castaneum were extensively studied using the residual film method. Results revealed that mortality increased proportionally with an increase in temperature, where the optimum temperature for the three tested insecticides was $30^{\circ} \mathrm{C}$. Toxicity of the tested insecticides could be arranged in the following descending order: chlorpyrifos-methyl >deltamethrin >malathion. Moreover, light exposure obviously enhanced toxicity of the three investigated insecticides compared to dark exposure. Piperonyl butoxide (PB) acted as an oxidase inhibitor, when mixed with each of the three insecticides, increased the toxicity ratio by about four fold in both dark and light. Joint toxic effects between deltamethrin and the two tested OP as esterase inhibitors, showed that mixing chlorpyrifosmethyl with deltamethrin increased deltamethrin toxicity by 152.7 and 137.12 fold in dark and light, respectively. Finally, deltamethrin + chlorpyrifos-methyl + PB blend was found to possess maximum efficiency, which increased deltamethrin toxicity by 679.05 fold under exposure to light conditions. Thus, modification of deltamethrin toxicity by increased temperature; light exposure and detoxification inhibitors maximized its toxicity to Tribolium castaneum, reduced insecticide rate, and thus reduces both the environmental stress, and the resistance pressure.
\end{abstract}

Keywords: Maximizing toxicity, deltamethrin, organophosphorus, Tribolium castaneum.

C hemical control of stored grain pests requires adequate and continuous attention to the storage rooms, during transportation, and to silo cells (Storey et al., 1984). Annual losses of stored grains caused by insects are estimated to be over $15 \%$ of the total stored grains produced in Egypt (Essa, 1995), and up to 9\% of the world's production (GIFAP, 1989).
The red flour beetle, Tribolium castaneum (Herbst) is one of the major insect pests of stored grain products in warm and tropical regions of the world (Semple, 1986). It is the most abundant and injurious pest in flour mills, bulks of grains, oilseeds and warehousing facilities (Zettler, 1991). Application of protectant insecticides is an integral part of the 
management of this pest (Bengston et al., 1991). Malathion has been used extensively for nearly 30 years as a grain protectant to control this pest, but now, it is losing its effectiveness due to insect resistance (Horton, 1984). Among the OP pesticide, chlorpyrifosmethyl is a possible substitute for malathion as a stored grain protectant for the malathion-resistant species particularly the T. castaneum (Collins et al., 1993). Since the grain insect pests are notorious for developing resistance to insecticides (Champ, 1986), and recently because there is a desire to reduce OP chemical residues on grains, alternatives to the OP have been sought by the grain protection industry. Most important of such alternatives are the $\alpha$-cyanophenoxy benzyl cyclopropanecarboxylate pyrethroid derivatives, particularly deltamethrin synergised with PB (Arthur, $1994 \mathrm{a} \& \mathrm{~b})$. However, high levels of resistance to pyrethroid insecticides have been reported in $T$. castaneum (Collins, 1990). Therefore, with two protectants being applied to grain, there is a potential for synergism between them (Daglish, 1998). Synergism between pyrethroids and organophosphorus insecticides has been demonstrated (Daglish, 1998 and Richter et al., 1998). However, the use of chemical treatment to control stored insects has been limited by the risk of insecticide resistance, cost, and consumer obstruction to using toxic chemicals on food or food products. This has resulted in reducing the maximum residue limits (Armitage et al., 1994). The aforementioned reasons have placed increasing reliance on the development of low-cost, low chemical input, and integrated pest management storage strategies that must be capable of guaranteeing the same degree of freedom from pests as chemical strategies. An integrated package of physical and chemical techniques had been recommended (Armitage et al., 1994). The interaction between physical factors such as temperature and moisture may be used to minimize the required dose of protectant (Shawir and Mansee, 1997). The effect of photo-period has also been considered (Montasser, 1999). Thus, different pesticides or pesticide combinations could be selected depending on the ambient environmental conditions under which the grain is to be stored.

The present investigation estimated the effects of light exposure and temperature, on the toxicity of deltamethrin, chlorpyrifos-methyl and malathion against $T$. castaneum. In addition, synergistic and joint toxic effects of tested insecticides after light exposure were evaluated against the tested insect pest. The final aim of this study was to investigate the management toxicity of tested insecticides against $T$. castaneum by using physical parameters. Specifically, it was observed whether mixtures and conditions could be exploited to increase the toxicity with a reduction in the application rates for the control of stored product insects.

\section{Materials and Methods}

INSECTS: Adults of red flour beetle, T. castaneum (Herbst) were laboratory cultured, and reared on sterilized whole meal flour ( $12 \%$ moisture content) in glass jars. Beetles were cultured at $25 \pm 2{ }^{\circ} \mathrm{C}$ and $70 \%$ \pm 5 R.h. The adults tested were 3-4 weeks old.

CHEMICALS: Deltamethrin [(S)- $\alpha$ cyano- 3-phenoxybenzyl (1R,3R)-3-(2,2-dibromovinyl)-2,2 dimethylcycloproanecarboxylate], technical grade $(\approx 98 \%$ a.i.); Chlorpyrifosmethyl [ O,O- dimethyl O-(3,5,6- trichloro-2-pyridinyl] phosphorothioate, $99.2 \%$ purchased from ChemService Inc. USA.; Malathion [O,O-dimethyl-5-(1,2-dicarbethoxymethyl) phosphorodithioate], technical grade (99.5\% a.i.); and piperonyl butoxide [5-\{[2-(2-butoxy ethoxy) ethoxy]methyl $\}$-6-propyl-1.3-benzodioxolie], as an oxidase inhibitor, was purchased from same source.

\section{BIOASSAY OF TESTED INSECTICIDES:}

\section{Effects of Light on Insecticide Toxicity at Different Temperatures}

Using a $1 \mathrm{ml}$ pipette, a $0.5 \mathrm{ml}$ sample of diluted insecticide solution (diluted with acetone), at the selected concentrations, was applied on a Whatman No. 1 filter paper $(7 \mathrm{~cm}$ i.d.), placed in a petri dish to ensure even chemical distribution (Shawir and Mansee, 1997). The filter paper was allowed to dry for approximately half hour. Twenty normally active adult beetles were transferred to each petri dish, confined by plastic rings, and incubated at $15,20,22,25$, and $30^{\circ} \mathrm{C}$. Dishes were kept in continuous light (14 W light source) in an incubator (Okiwelu et al., 1998). Another group of petri dishes was kept under continuous dark conditions for comparison. Beetles were examined after 5 days of exposure and the mortality counts were recorded. Each group included seven concentrations and a control, each in three replicates. The $\mathrm{LC}_{50}$ values expressed as $\mu \mathrm{g} / \mathrm{cm}^{2}$ were calculated according to Finney (1971).

\section{Synergism and Joint Toxic Effect of Tested Insecticides}

Synergism of tested insecticides: Piperonyl butoxide (PB) was mixed, as an oxidase inhibitor, with each tested insecticides at the ratio of 1:5. Blends were tested against $T$. castaneum using the residual film method as previously mentioned, and were incubated at $30^{\circ} \mathrm{C}$ for tested insecticides, under continuous darkness or light. Toxicity and synergistic effect were computed according to the method of Metcalf (1967).

Joint toxic effects of synthetic pyrethroid, deltamethrin: Series of deltamethrin concentrations were mixed with malathion or chlorpyrifos-methyl at the ratio of 1:5 to evaluate the joint toxic effects between insecticides according to Bengston et al. (1987). The residual film application method as previously described was followed and treated insects were kept at the optimum 
temperature degree, $30^{\circ} \mathrm{C}$ (Shawir and Mansee, 1997). The joint toxic effect was studied by mixing deltamethrin with the OP insecticide, chlorpyrifosmethyl, as an esterase inhibitor, and piperonyl butoxide, as an oxidase inhibitor. Deltamethrin was mixed with chlorpyrifos-methyl and piperonyl butoxide at the ratio of 1:4:8 respectively according to Bengston et al. (1983). The residual film application, as previously described, was used against T. castaneum at $30^{\circ} \mathrm{C}$ under continuous darkness or light for 5 days to evaluate the joint toxicity action. The $95 \%$ fiducial limits of the $\mathrm{LC}_{50}$ values were used to test for the statistical significant differences in toxicity between different treatments (Koziol and Witkowski, 1982).

\section{Results and Discussion}

ROLE OF TEMPERATURE AND LIGHT EXPOSURE ON INSECTICIDE TOXICITY: Influences of temperature as well as exposure to source of light, on the toxicity of tested insecticides, deltamethrin, chlorpyrifos-methyl and malathion, against adults of $T$. castaneum, were extensively investigated. Results are presented in Figure $1 \mathrm{a}, \mathrm{b}$, and $\mathrm{c}$, as toxicity ratios of tested insecticide, under continuous darkness or light conditions at different temperatures. Toxicity ratio was calculated by dividing the lowest toxicity value $\left(\mathrm{LC}_{50}\right.$ of malathion treatment in darkness at $30^{\circ} \mathrm{C}$, as 5.717 $\mu \mathrm{g} / \mathrm{cm}^{2}$ ), with $\mathrm{LC}_{50}$ values of each treatment. The Duncan test was used to test for the statistically significant differences in toxicity ratio among different temperature levels (Herzberg, 1983). Present results show that the toxicity of tested insecticides against $T$. castaneum after exposure to the light is higher than those of the corresponding toxicity in dark at each examined temperature. In addition, the data showed that the toxicity of tested insecticides to $T$. castaneum increased with a temperature increase, either in light or in dark, except in the case of deltamethrin. The toxicity ratio of deltamethrin treatments at 20,22 , and $25^{\circ} \mathrm{C}$ under continuous light or dark against $T$. castaneum seems to be negatively correlated with temperature. The present study also revealed a margin of temperature range at which deltamethrin exerts a negative temperature-toxicity correlation.

The optimum temperature was found to be $30^{\circ} \mathrm{C}$ for insecticides against $T$. castaneum under light or dark exposure. Moreover, chlorpyrifos-methyl was more toxic than deltamethrin or malathion at all temperatures under light or dark exposure. The toxicity ratios of chlorpyrifos-methyl values were calculated to be 6.381 and 12.138 folds at $30^{\circ} \mathrm{C}$ under darkness and light treatments, respectively against $T$. castaneum.

The current investigation revealed that synthetic pyrethroid, deltamethrin toxicity ratios at 20,22 , and $25^{\circ} \mathrm{C}$, were negatively correlated with temperature. This is in agreement with the findings of Longstaff and Desmarchlier (1983) who reported that the toxicity of a.

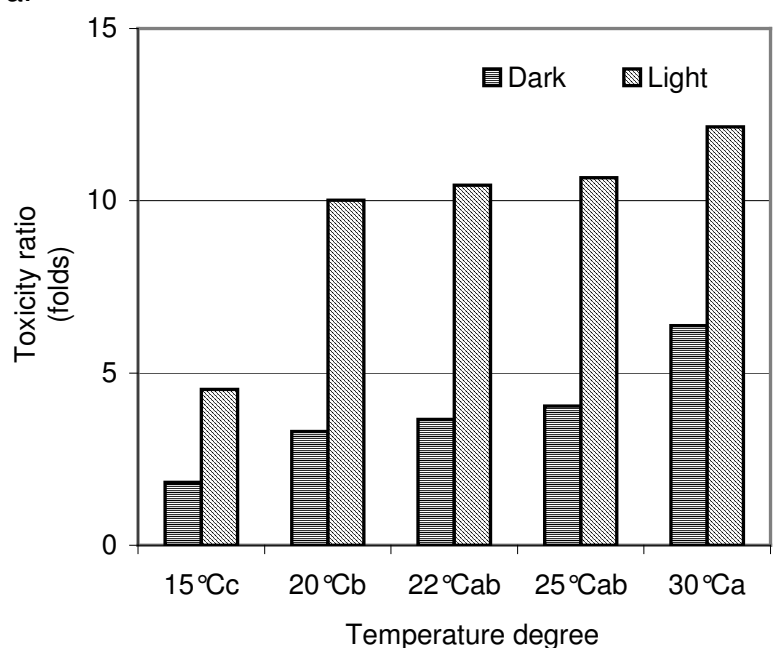

b.

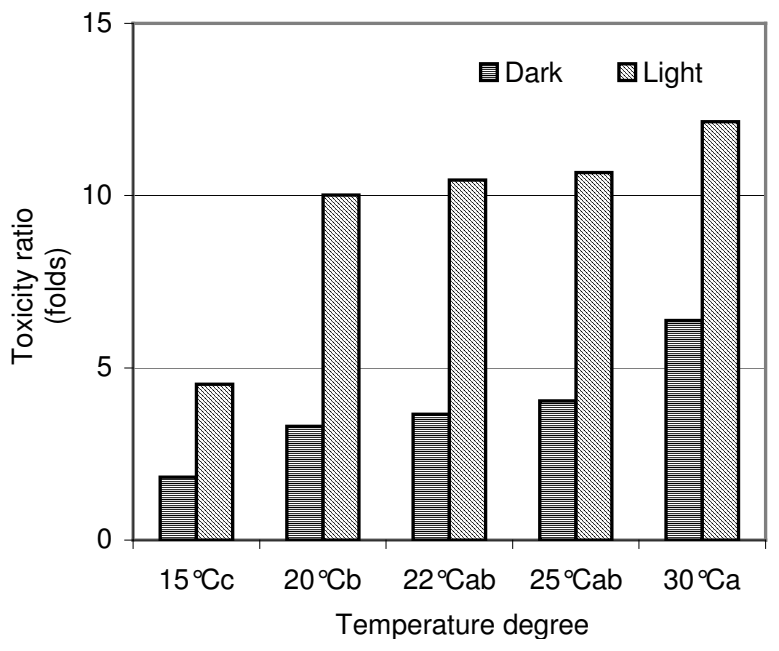

c.

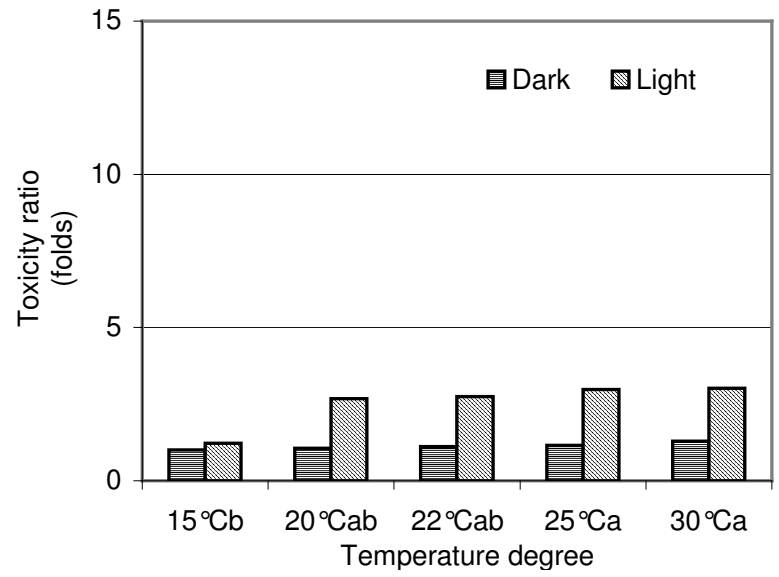

Figure 1. a. Effect of temperature on toxicity of deltamethrin against $T$. castaneum. b. Effect of temperature on toxicity of chlorpyrifos-methyl against T. castaneum. c. Effect of temperature on toxicity of malathion against $T$. castaneum. Toxicity ratio values for a given temperature followed by a common letter are not significantly different as Duncan test.

deltamethrin to $S$. oryzae decreased with increasing temperature. However, Watters et al., (1983) reported that the toxicity of the pyrethroid insecticides cypermethrin and fenvalerate to $T$. castaneum was significantly higher at $20^{\circ} \mathrm{C}$ than at $10^{\circ} \mathrm{C}$ or $30^{\circ} \mathrm{C}$. 
Moreover, Shawir and Mansee (1997) reported that toxicity of the tetrahalo-pyrethroid tralomethrin to $S$. oryzae and $T$. castaneum using residual application was higher at $25^{\circ} \mathrm{C}$ than at $35^{\circ} \mathrm{C}$ or $15^{\circ} \mathrm{C}$. They also reported that deltamethrin was more toxic at the higher temperature $\left(35^{\circ} \mathrm{C}\right)$ for residual exposure against $S$. oryzae and $T$. castaneum. In other words, very low or very high temperature might have a severe effect on the biological and physiological activities of the insect that in turn may affect insect susceptibility to pyrethroids. The same trend of temperature-toxicity interaction was observed by Montasser (1999). Also, it was cited that the pyrethroid insecticide permethrin expressed a higher effect at $20^{\circ} \mathrm{C}$ than at 30 , or $15^{\circ} \mathrm{C}$ to both tested insects.

The present investigation showed that the toxicity of two tested OP's, malathion and chlorpyrifos-methyl, increased by increasing temperature. Toxicity also increased as a result of light exposure rather than dark conditions. Desmarchelier (1977) indicated the effect of lower temperature and supported these findings in reducing toxicity of organophosphorus, dichlorvos, malathion, fentriothion and pirimiphos-methyl against Tribolium and Sitophilus species. In addition, Tyler and Binns (1982) mentioned that the effectiveness of malathion and pirimiphos-methyl against the examined susceptible stored product insects was greater at $25^{\circ} \mathrm{C}$ than at $17.5^{\circ} \mathrm{C}$ and was markedly lower at $10^{\circ} \mathrm{C}$. Montasser (1999) added that tested organophosphorus insecticides, pirimiphos-methyl and malathion were more toxic at higher temperature against $S$. oryzae and T. castaneum. In contrast, Longstaff and Desmarchlier (1983) showed that the pirimiphos-methyl was shown to have opposite relationships with temperature to $S$. oryzae.

The present results show that the three tested insecticides could be arranged in a descending order according to their toxicity to $T$. castaneum at all examined temperatures as chlorpyrifos-methyl, deltamethrin and malathion. The present investigation also showed that light exposure plays an important role in the toxicity of each of the tested insecticides against $T$. castaneum. However, the toxicity of these insecticides was increased when exposed to light at the same temperature. It can also be concluded that light exposure increases the toxicity ratio compared to darkness by $280,190.2$, and $235.03 \%$ for deltamethrin, chlorpyrifos-methyl and malathion treatments respectively, at optimum temperature $\left(30^{\circ} \mathrm{C}\right)$.

Previous work emphasized that the effects of exposure to light on the toxicity of pesticides especially for stored product insects are few. Fernandez and Randolph (1966) mentioned that the photoperiodic rearing conditions affect the susceptibility of houseflies to a given dosage of insecticides. It could be explained according to the assumption of Pittendrigh (1961), who found that the photoperiod could exert effects on other fundamental aspects of insect physiology. El-Sebae and
Moustafa (1970) studied the effect of three photoperiodic treatments such as continuous illuminating, 12 hours periodic light and dark and continuous darkness on the life cycle and susceptibility of $M$. domestica to DDT. They concluded that continuous illumination increased the activity of the insects. This might render the insects more vulnerable to DDT poising. Okiwelu et al. (1998) added that the photoperiod affects some aspects of the biology of the merchant grain beetle, Oryzaephilus mercator. Montasser (1999) supported the present findings and concluded that the toxicity of permethrin, pirimiphosmethyl and malathion after exposure to light, was higher than the corresponding toxicity in absence of light against both $S$. oryzae and $T$. castaneum.

INFLUENCE OF PB ON SYNERGISM OF TESTED INSECTICIDES: Synergistic effects of the oxidase inhibitor, piperonyl butoxide (PB) on the toxicity of insecticides at their optimum temperature $\left(30^{\circ} \mathrm{C}\right)$ against $T$. castaneum, under continuous darkness or continuous light, are presented in Table 1 . The $\mathrm{LC}_{50}$ values for given treatments were compared. The significant differences between $\mathrm{LC}_{50}$ values were detected by using the $95 \%$ fiducial limits (Koziol and Witkowski, 1982). The results show that addition of the oxidase inhibitor (PB) to deltamethrin, chlorpyrifosmethyl and malathion resulted in a remarkable synergism against $T$. castaneum under both exposure operations. In addition, synergistic ratios in the continuous light treatment were higher than those under darkness treatment for all tested insecticides. The toxicity of chlorpyrifos-methyl $+\mathrm{PB}$ blends against $T$. castaneum after exposure to light was the most toxic than all other tested insecticide blends, showed 0.115 $\mu \mathrm{g} / \mathrm{cm}^{2}$ and 4.09 folds as $\mathrm{LC}_{50}$ and synergistic ratio, respectively. Furthermore, mixing PB with malathion resulted in the highest synergism, against $T$. castaneum. The values were calculated as 4.84 and 4.49 folds for darkness and light treatments conditions, respectively.

Mixed function oxidase (MFO) plays a significant role in degradation of pyrethroid insecticides (Yamamoto, 1973) or organophosphorus insecticides (Attia and Frecker, 1984). However, using piperonyl butoxide, well known as an MFO inhibitor, could be classified as an active synergist with all tested insecticides (Wilkinson, 1971). Thus, inhibition of these types of enzymes by $\mathrm{PB}$ is a possible explanation for the high level of synergism (Lloyd, 1973).

Adding PB to the three tested insecticides, in the present investigation, resulted in a remarkable synergism against $T$. castaneum. This result can be supported by the report of Bengston et al. (1983), who indicated that deltamethrin + pirimiphos-methyl + PB blend completely controlled $S$. oryzae (L.), T. castaneum, T. confusum and $R$. dominica. Marei et al. (1994) added that PB synergized the toxicity of deltamethrin against S. oryzae (L.). On the other hand, Wanas et al. (1982) 
TABLE 1

Effects of oxidase inhibitor, piperonyl butoxide $(P B)$, on insecticides toxicity to T. castaneum using residual film method at $30^{\circ} \mathrm{C}$.

\begin{tabular}{|c|c|c|c|c|c|}
\hline \multirow{3}{*}{ Insecticides } & & \multicolumn{4}{|c|}{ Treatments } \\
\hline & & \multicolumn{2}{|c|}{ In Dark } & \multicolumn{2}{|c|}{ In Light } \\
\hline & & $\begin{array}{c}\mathrm{LC}_{50}\left(\mu \mathrm{g} / \mathrm{cm}^{2}\right) \\
\text { (95\% Fiducial Limits) } \\
\end{array}$ & $\begin{array}{c}\text { Toxicity Ratio** } \\
\text { (Fold) }\end{array}$ & $\begin{array}{c}\mathrm{LC}_{50}\left(\mu \mathrm{g} / \mathrm{cm}^{2}\right) \\
\text { (95\% Fiducial Limits) }\end{array}$ & $\begin{array}{c}\text { Toxicity Ratio** } \\
\text { (Fold) }\end{array}$ \\
\hline \multirow{2}{*}{ Deltamethrin } & Without PB & $\begin{array}{l}2.00 \\
(1.72-2.40)\end{array}$ & - & $\begin{array}{l}0.713 \\
(0.64-0.79)\end{array}$ & - \\
\hline & $+\mathrm{PB}$ & $\begin{array}{l}0.625^{*} \\
(0.57-0.68)\end{array}$ & 3.2 & $\begin{array}{l}0.166^{*} \\
(0.14-0.19)\end{array}$ & 4.3 \\
\hline \multirow{2}{*}{ Chlorpyrifos-methyl } & Without PB & $\begin{array}{l}0.896 \\
(0.82-0.97)\end{array}$ & - & $\begin{array}{l}0.471 \\
(0.40-0.54)\end{array}$ & - \\
\hline & $+\mathrm{PB}$ & $\begin{array}{l}0.228^{*} \\
(0.20-0.26)\end{array}$ & 3.93 & $\begin{array}{l}0.115^{*} \\
(0.10-0.13)\end{array}$ & 4.09 \\
\hline \multirow{2}{*}{ Malathion } & Without PB & $\begin{array}{l}4.442 \\
(4.1-4.82)\end{array}$ & - & $\begin{array}{l}1.89 \\
(1.76-2.03)\end{array}$ & - \\
\hline & $+\mathrm{PB}$ & $\begin{array}{l}0.918 * \\
(0.84-0.99)\end{array}$ & 4.84 & $\begin{array}{l}0.421 * \\
(0.39-0.45)\end{array}$ & 4.49 \\
\hline
\end{tabular}

$* \mathrm{LC}_{50}$ values followed by asterisks are significantly greater than without $\mathrm{PB}$ based on the $95 \%$ fiducial limits.

$* *$ Relative to the toxicity of insecticide without synergism (PB).

reported that PB could be used successfully as a synergist for malathion and other organophosphorus insecticides against $S$. oryzae. Moreover, Bengston et al. (1983) mentioned that pirimiphos-methyl + PB controlled common field strains of $S$. oryzae and $R$. dominica. The addition of PB to malathion was also attempted to increase the toxicity of this organophosphorus against $O$. surinamensis (Attia and Frecker, 1984). Montasser (1999) mentioned that mixing of PB with permethrin, pirimiphos-methyl and malathion resulted in a synergistic effect of toxicity against both $S$. oryzae and $T$. castaneum. The tested insecticide-synergist mixtures can be arranged in the following descending toxicity order: Pirimiphos-methyl $+\mathrm{PB}$ at $30^{\circ} \mathrm{C}>$ permethrin $+\mathrm{PB}$ at $20^{\circ} \mathrm{C}>$ malathion + $\mathrm{PB}$ at $30^{\circ} \mathrm{C}$.

INFLUENCE OF ESTERASE INHIBITORS ON TOXICITY OF DELTAMETHRIN: Organophosphorus insecticides when mixed with pyrethroids used to play a role as an esterase inhibitor, which result in increasing the toxicity of pyrethroids (Marei et al., 1982). Thus the joint toxic effects of chlorpyrifos-methyl and malathion, as an esterase inhibitors when mixed with deltamethrin, were extensively evaluated against $T$. castaneum at $30^{\circ} \mathrm{C}$ in continuous light or darkness (Table 2). The results show that inhibitors, when mixed with deltamethrin, significantly enhance its insecticidal toxicity against the tested insect in light and darkness conditions. However, when deltamethrin was mixed with chlorpyrifos-methyl, the blend was more toxic than the deltamethrin-malathion mixture under dark or light conditions. The $\mathrm{LC}_{50}$ of the mixture (deltamethrin-chlorpyrifos-methyl) against $T$. castaneum under continuous dark treatment was 0.0131 $\mu \mathrm{g} / \mathrm{cm}^{2}$ with toxicity ratio of 152.7 folds, while in continuous light treatment the values were $0.0052 \mu \mathrm{g} / \mathrm{cm}^{2}$ and 137.12 folds, respectively. Meanwhile, the two tested deltamethrin-organophosphorus mixtures, showed more toxicity under light treatment than under dark treatment.

Organophosphorus compounds were classified as exceptionally potent pyrethroid esterase inhibitors (Marei et al., 1982). The esterase enzymes play an important role in detoxification and degradation of pyrethroid insecticides. The inhibition of these enzymes by OP compounds enhanced pyrethroids persistence (Mansee, 1992).

The organophosphorus compounds, chlorpyrifosmethyl and malathion as esterase inhibitors, showed an effect on the insecticidal activity when used in mixtures with pyrethroid insecticide (deltamethrin) against the adults of $T$. castaneum (Herbst). Current findings may

TABLE 2

Effects of esterase inhibitors on Deltamethrin toxicity against T. castaneum using residual film method at $30^{\circ} \mathrm{C}$.

\begin{tabular}{|c|c|c|c|c|}
\hline \multirow[b]{3}{*}{ Insecticides } & \multicolumn{4}{|c|}{ Treatments } \\
\hline & \multicolumn{2}{|c|}{ In Dark } & \multicolumn{2}{|l|}{ In Light } \\
\hline & $\begin{array}{c}\mathrm{LC}_{50}\left(\mu \mathrm{g} / \mathrm{cm}^{2}\right) \\
\text { (95\% Fiducial } \\
\text { Limits) }\end{array}$ & $\begin{array}{l}\text { Toxicity } \\
\text { Ratio* } \\
\text { (Fold) }\end{array}$ & $\begin{array}{c}\mathrm{LC}_{50}\left(\mu \mathrm{g} / \mathrm{cm}^{2}\right) \\
\text { (95\% Fiducial } \\
\text { Limits) }\end{array}$ & $\begin{array}{l}\text { Toxicity } \\
\text { Ratio* } \\
\text { (Fold) } \\
\end{array}$ \\
\hline Deltamethrin & $\begin{array}{l}2.00^{\mathrm{a}} \\
(1.72-2.40)\end{array}$ & 0 & $\begin{array}{l}0.713^{\mathrm{b}} \\
(0.64-0.79)\end{array}$ & 0 \\
\hline $\begin{array}{l}\text { Deltamethrin } \\
+ \text { Malathion }\end{array}$ & $\begin{array}{l}0.16^{\mathrm{c}} \\
(0.14-0.18)\end{array}$ & 12.5 & $\begin{array}{l}0.0174^{\mathrm{d}} \\
(0.013-0.023)\end{array}$ & 41 \\
\hline $\begin{array}{l}\text { Deltamethrin } \\
\text { +Chlorpyrifos- } \\
\text { methyl }\end{array}$ & $\begin{array}{l}0.0131^{\mathrm{d}} \\
(0.0081-0.013)\end{array}$ & 152.7 & $\begin{array}{l}0.0052^{\mathrm{e}} \\
(0.0042-0.0063)\end{array}$ & 137.12 \\
\hline
\end{tabular}

*Relative to the toxicity of deltamethrin alone.

$\mathrm{LC}_{50}$ values for a given treatment followed by a common letter are not significantly different at the $5 \%$ level of probability based on the $95 \%$ fiducial limits. 
TABLE 3

Joint toxic effects of Deltamethrin toxicity against $\mathbf{T}$. castaneum using residual film method at $30^{\circ} \mathrm{C}$.

\begin{tabular}{|c|c|c|c|c|}
\hline \multirow[b]{3}{*}{ Insecticides } & \multicolumn{4}{|c|}{ Treatments } \\
\hline & \multicolumn{2}{|c|}{ In Dark } & \multicolumn{2}{|l|}{ In Light } \\
\hline & $\begin{array}{c}\mathrm{LC}_{50}\left(\mu \mathrm{g} / \mathrm{cm}^{2}\right) \\
\text { (95\% Fiducial } \\
\text { Limits) }\end{array}$ & $\begin{array}{l}\text { Toxicity } \\
\text { Ratio* } \\
\text { (Fold) }\end{array}$ & $\begin{array}{c}\mathrm{LC}_{50}\left(\mu \mathrm{g} / \mathrm{cm}^{2}\right) \\
\text { (95\% Fiducial } \\
\text { Limits) } \\
\end{array}$ & $\begin{array}{c}\text { Toxicity } \\
\text { Ratio* } \\
\text { (Fold) } \\
\end{array}$ \\
\hline Deltamethrin & $\begin{array}{l}2.00^{\mathrm{a}} \\
(1.72-2.40)\end{array}$ & - & $\begin{array}{l}0.713^{\mathrm{b}} \\
(0.64-0.79)\end{array}$ & - \\
\hline $\begin{array}{l}\text { Deltamethrin } \\
+\mathrm{PB}\end{array}$ & $\begin{array}{l}0.625^{\mathrm{b}} \\
(0.57-0.68)\end{array}$ & 3.2 & $\begin{array}{l}0.166^{\mathrm{c}} \\
(0.14-0.19)\end{array}$ & 4.3 \\
\hline $\begin{array}{l}\text { Deltamethrin + } \\
\text { Chlorpyrifos- } \\
\text { methyl }\end{array}$ & $\begin{array}{l}0.013^{\mathrm{d}} \\
(0.0081-0.013)\end{array}$ & 152.7 & $\begin{array}{c}0.0052^{\mathrm{e}} \\
(0.0042- \\
0.0063)\end{array}$ & 137.12 \\
\hline $\begin{array}{l}\text { Deltamethrin + } \\
\text { Chlorpyrifos- } \\
\text { methyl + PB }\end{array}$ & $\begin{array}{l}0.0056^{\mathrm{e}} \\
(0.0046-0.0069)\end{array}$ & 357.14 & $\begin{array}{c}0.00106^{\mathrm{f}} \\
(7.9 \mathrm{E} 4-1.41 \mathrm{E} 3)\end{array}$ & 679.05 \\
\hline
\end{tabular}

*Relative to the toxicity of deltamethrin alone.

$\mathrm{LC}_{50}$ values for a given treatment followed by a common letter are not significantly different at the $5 \%$ level of probability based on the $95 \%$ fiducial limits.

also be supported by Carter et al. (1980) who found that chlorpyrifos-methyl, pirimiphos-methyl or fenitrothion in combination with permethrin resulted in potentiation for control of stored product insect pests. Bengston et al. (1983) added that pirimiphos-methyl + permethrin controlled S. oryzae (L.) and R. dominica, and completely prevented progeny production in $T$. castaneum, $T$. confusm and in E. cautella. Conversely, a mixture of permethrin and pirimiphos-methyl was less effective against $P$. truncatus and $S$. zeamis (Richter et al., 1998). Marei et al. (1994) found that mixing profenfos with deltamethrin resulted in enhancement of permethrin toxicity against the rice weevil, S. oryzae (L.). Also, the toxicity of pyrethroids to stored product insects was increased when mixed with other organophosphorus insecticides such as Chlorpyrifos-methyl (Daglish, 1998). Montasser (1999) concluded that the addition of the organophosphorus, TOCP, malathion and pirimiphosmethyl resulted in potentiation of the insecticidal toxicity of permethrin against the adults of $S$. oryzae (L.) and $T$. castaneum (Herbst). This is in agreement with our investigation. The toxicity of the mixtures against insects can be arranged in the following descending order: permethrin+ pirimiphos-methyl $>$ permethrin + malathion $>$ permethrin + TOCP $>$ permethrin alone.

EFFECTS OF ESTERASE AND OXIDASE INHIBITOR COMBINATION ON DELTAMETHRIN TOXICITY: To study the joint toxic effect against $T$. castaneum, deltamethrin was mixed with chlorpyrifos-methyl and $\mathrm{PB}$, at the ratio of 1:4:8 and kept at $30^{\circ} \mathrm{C}$ under continuous darkness and light conditions. The mixture gave $\mathrm{LC}_{50}$ and toxicity ratio values of $5.6 \times 10^{-3} \mu \mathrm{g} / \mathrm{cm}^{2}$ and 357.14 folds under continuous darkness and $1.06 \times 10^{-3} \mu \mathrm{g} / \mathrm{cm}^{2}$ and 679.05 folds in continuous light, respectively (Table 3 ). This mixture exhibited the most significant synergistic effect among all tested mixtures or deltamethrin alone.

The activity of deltamethrin, chlorpyrifos -methyl, and PB mixture showed an obvious effect over the activity of deltamethrin alone against $T$. castaneum. Generally, the relative toxicity of this mixture proved the highest ratio in the present study either in darkness or light conditions against tested insects.

The toxicity of the different mixtures with deltamethrin against stored-product insects could be arranged in the following descending order: deltamethrin plus chlorpyrifos-methyl plus $\mathrm{PB}>$ deltamethrin plus chlorpyrifos-methyl $>$ deltamethrin plus $\mathrm{PB}>$ deltamethrin. In addition, all tested treatments showed a better effect to $T$. castaneum under light than under darkness condition.

COMPARING INSECTICIDE TOXICITY UNDER DIFFERENT CONDITIONS WITH RECOMMENDED APPLICATION RATE: The results showed that the used unit of malathion in dark at $25^{\circ} \mathrm{C}$ was $100 \mu \mathrm{g} / \mathrm{cm}^{2}$, while at $30^{\circ} \mathrm{C}$, the same value was $88.84 \mu \mathrm{g} / \mathrm{cm}^{2}$ (Table 4). Both chlorpyrifosmethyl and deltamethrin, when tested in darkness at $30^{\circ} \mathrm{C}$, showed increased toxicity against $T$. castaneum compared with malathion (used units was 17.36 and 40 $\mu \mathrm{g} / \mathrm{cm}^{2}$, respectively). The suggested blend of deltamethrin + chlorpyrifos-methyl $+\mathrm{PB}$ in dark at $30^{\circ} \mathrm{C}$, increased the toxicity value by decreasing the units used $\left(0.112 \mu \mathrm{g} / \mathrm{cm}^{2}\right)$.

The toxicity values were expressed as 20 times of each $\mathrm{LC}_{50}\left(\mu \mathrm{g} / \mathrm{cm}^{2}\right)$. The $\mathrm{LC}_{50}$ multiplied by 20 times, to simulate the dose of malathion recommended to control empty silos in Egypt (suggested by the Egyptian Ministry of Agriculture, 1997) as $100 \mu \mathrm{g} / \mathrm{cm}^{2}$ of malathion at $25^{\circ} \mathrm{C}$, which equal to 20 times of its $\mathrm{LC}_{50}$ at the same conditions in the present study.

All the previous treatments when tested under light condition, increased the toxicity value of the treatment compared to the recommended application. The same table showed how much the treatments and blends save or decrease the amounts of insecticides used as compared to the recommended application by the Ministry.

TABLE 4

Comparative toxicity of tested insecticides under different conditions with special reference to the recommended application.

\begin{tabular}{lccllll}
\hline \multirow{2}{*}{ Treatments } & \multicolumn{2}{c}{$\begin{array}{c}\text { Units Used } \\
\left(\mu \mathrm{g} / \mathrm{cm}^{2}\right)\end{array}$} & & \multicolumn{2}{c}{$\begin{array}{c}\text { Units Saved } \\
(\%)\end{array}$} \\
\cline { 2 - 3 } \cline { 6 - 7 } & \multicolumn{2}{c}{ In Dark } & In Light & & In Dark & In Light \\
\hline Malathion $\left(25^{\circ} \mathrm{C}\right)$ & $100.00^{*}$ & 38.30 & & - & 61.70 \\
Malathion $\left(30^{\circ} \mathrm{C}\right)$ & 88.84 & 37.80 & & 11.16 & 62.20 \\
Chlorpyrifos-methyl $\left(30^{\circ} \mathrm{C}\right)$ & 17.36 & 9.42 & & 82.64 & 90.58 \\
Deltamethrin $\left(30^{\circ} \mathrm{C}\right)$ & 40.00 & 14.26 & & 60.00 & 85.74 \\
Deltamethrin+Chlorpyrifos- & 0.11 & 0.02 & & 99.88 & 99.98 \\
Methyl + PB $\left(30^{\circ} \mathrm{C}\right)$ & & & & & \\
\hline
\end{tabular}

*Recommended dose of malathion in empty silos in Egypt at $25^{\circ} \mathrm{C}$ according to the Egyptian Ministry of Agriculture (1997), which is equal to 20 times of $\mathrm{LC}_{50}$ 's malathion at $25^{\circ} \mathrm{C}$ in dark. 
It can be concluded that exposure to light saves more than $60 \%$ of the malathion dose, while in the case of chlorpyrifos-methyl and deltamethrin, savings reached $90 \%$ and $85 \%$, respectively. The suggested blend in the present study might be used as an alternative to malathion. This will help to save about $99 \%$ of malathion units used in the regular recommendation.

\section{Conclusions}

Light exposure increases the toxicity of the tested insecticides against $T$. castaneum, compared to darkness exposure at all examined temperatures. The toxicity value increased proportionally with an increase in temperature. The optimum temperature level for the three examined insecticides was $30^{\circ} \mathrm{C}$. Both oxidase and esterase inhibitors, when mixed with deltamethrin, increased the toxicity values in darkness and light. Moreover, modification of deltamethrin toxicity by temperature, light exposure and inhibitors resulted in an increase in the toxicity, thus reducing insecticide quantities required and minimizing environment pressures. Finally, to obtain the optimum efficacy it is suggested that the blend deltamethrin + chlorpyrifosmethyl $+\mathrm{PB}$ should be used at $30^{\circ} \mathrm{C}$ under light condition to protect stored products warehouses from $T$. castaneum infestation.

\section{References}

Anonymous. 1997. Pest Control Program, Ann. Periodic. Ed., by Egyptian Ministry of Agriculture. pp 95.

Armitage, D.M., P.M. Cogan, and D.R. Wilkin. 1994. Integrated pest management in stored grain: Combining surface insecticide treatments with aeration. Journal of Stored Products Research 30(4):303-319.

Arthur, F.H. 1994a. Grain protectant chemicals: Present status and future trends. In: Proceedings of the $6^{\text {th }}$ International Working Conference on Stored-Product Protection, E.J. Wright, H.J. Banks and B.R. Champ (Editors), 719-721. Canberra, Australia.

Arthur, F.H. 1994b. Efficacy of unsynergsied deltamethrin and deltamethrin + chlorpyrifos-methyl combinations as protectants for stored wheat and stored corn maize. Journal of Stored Products Research 30(1):87-94.

Attia, F.I. and T. Frecker. 1984. Cross-resistance spectrum and synergism studies in organophosphorus-resistant strain of Oryzaephilus surinamensis (L.) (Coleoptera: Cucujidae) in Australia. Journal of Economic Entomology 77(3):1367-1370.

Bengston, M., R.A.H. Davies, J.M. Desmarchelier, R. Henning, W. Murrey, B.W. Simpson, J.T. Snelson, R. Sticka and B.E. Wallbank. 1983. Organophosphorothioates and synergised synthetic pyrethroids as grain protectants on bulk wheat. Pesticides Science 14(2): 373-384.

Bengston, M., J.M. Desmarchelier, B. Hayward, R. Henning, J.H. Moulden, R.M. Noble, G. Smith, J.T. Snelson, R. Sticka, S. Thomas, B.E. Wallbank, and D.J. Webley. 1987. Synergised cyfluthrin and cypermethrin as grain protectants on bulk wheat. Pesticides Science 21(1):23-37.

Bengston, M., K. Kock and A.C. Strange.1991. Chemical control methods. In: Proceedings of the $5^{\text {th }}$ International Working Conference on Stored-Product Protection. F. Fleurat-Lessard and P. Ducom (Editors), 471-82. Bordeaux, France.
Carter, S.W., J. Ardley, and P.R. Skidmore. 1980. Insecticide composition. African, 79,01:632, c.f. Chemical Abstract. 1980. 94:151905.

Champ, B.R. 1986. Occurrence of resistance to pesticides in grain storage pests: Pesticides and Humid Tropical Grain Storage Systems. In: ACIAR Proceedings No. 14, B.R. Champ and E. Highley (Editors), 229-255. ACIAR, Canberra, Australia.

Collins, P.J. 1990. A new resistance to pyrethroids in Tribolium castaneum (Herbst). Pesticides Science 28(1):101-115.

Collins, P.J., T.M. Lambkin, B.W. Bridgeman, and C. Pulvirenti. 1993. Resistance to grain-protectant insecticides in coleopterous pests of stored cereals in Queensland, Australia. Journal of Economic Entomology 86(1):239-245.

Daglish, G.J. 1998. Efficacy of six grain protectants applied alone or in combination against three species of Coleoptera. Journal of Stored Products Research 34(4):263-268.

Desmarchelier, J.M. 1977. Selective treatments, including combinations of pyrethroid and organophosphorus insecticides for control of stored product Coleoptera at two temperatures. Journal of Stored Products Research 13(2):129-137.

El-Sebae, A. and F.I. Moustafa. 1970. The effect of photoperiodism on the life cycle of house flies and their susceptibility to insecticides. Alexandria Journal of Agricultural Research 18(1):135-139.

Essa, I.S. 1995. Insect and animal pests of stored products and its control methods in Egypt and other Arab countries. Arabic Company for Edition and Distribution, Cairo, Egypt.

Fernandez, A.T. and N.M. Randolph. 1966. The susceptibility of houseflies reared under various photoperiods to insecticide residues. Journal of Economic Entomology 59(1):37-39.

Finney, J. 1971. Probit analysis, $2^{\text {nd }}$ ed. Cambridge University Press, Cambridge.

GIFAP. 1989. A summary of the IRAC survey on resistance in stored grain pests. GIFAP Newsl. 3:1-7.

Herzberg, P.A. (ed.). 1983. Principles of statistics. York University, John Wiley and Sons, U.S.A.

Horton, P.M. 1984. Evaluation of South Carolina field strains of certain stored-product Coleoptera for malathion resistance and pirimiphos-methyl susceptibility. Journal of Agricultural Entomology $1(1): 1-5$.

Koziol, F.S. and J.F. Witkowski. 1982. Synergism studies with binary mixtures of permethrin plus methyl parathion, chlorpyrifos, and malathion on European corn borer larvae. Journal of Economic Entomology 75(1):28-30.

Lloyd, C.J. 1973. The toxicity of pyrethrins and five synthetic pyrethroids to Tribolium castaneum (Herbst) and susceptible and pyrethrins-resistant Sitophilus granarius. Journal of Stored Products Research 9(1):77-92.

Longstaff, B.C. and J.M. Desmarchelier. 1983. The effects of the temperature-toxicity relationships of certain pesticides upon the population growth of Sitophilus oryzae (L.) (Coleoptera: Curculonidae). Journal of Stored Products Research 19(1):25-29.

Mansee, A.H. 1992. Chemical analysis and biological interaction of deltamethrin and tralomethrin in treated rats. Ph.D. Thesis. Faculty of Agriculture, Alexandria University, Egypt.

Marei, A.M., M.M. Khattab, and M.R. Montasser. 1994. Toxicity, joint toxic effect and synergism of certain pyrethroids against the rice weevil, Sitophilus oryzae. Alexandria Journal of Agricultural Research 39(3):347-362.

Marei, A.M., L.O. Ruzo, and J.E. Casida. 1982. Analysis and persistence of permethrin, cypermethrin, deltamethrin and fenvalerate in fat and brain of treated rats. Journal of Agricultural and Food Chemistry 30(3):558-562.

Metcalf, R.L. 1967. Mode of action of insecticide synergists. Annual Review of Entomology 12:229-256.

Montasser, M.M.R. 1999. Studies on control of certain stored product pests. Ph.D. Thesis. Faculty of Agriculture, Alexandria University, Egypt.

Okiwelu, S.N., P.O. Dudu, and N.E.S. Lale. 1998. The effects of photoperiod on some aspects of biology of Oryzaephilus mercator (Fauvel) (Coleoptera: Silvanidae). Journal of Stored Products Research 34(2/3):189-193. 


\section{MANSEE AND MONTASSER}

Pittendrigh, C.S. 1961. On temporal organization in living systems. Harvey Lectures Series 56:93-125.

Richter, J., A. Biliwa, and S.H. Helbig. 1998. Efficacy of dust formulated insecticides in traditional maize stored in West Africa. Journal of Stored Products Research 34(2/3):181-187.

Semple, R.L. 1986. Problems relating to pest control and use of pesticides in grain storage: the current situation in ASEAN and future requirements. In: Pesticides and Humid Tropical Grain Storage System: ACIAR Proceedings No. 14, B.R. Champ and E. Highley (Editors), 45-75.ACIAR, Canberra, Australia.

Shawir, M.S. and A.H. Mansee. 1997. The influence of temperature on the residual toxicity of deltamethrin and tralomethrin to Sitophilus oryzae and Tribolium castaneum. Alexandria Journal of Agricultural Research 42(3):207-215.

Storey, C.L., D.B. Sauer, and D. Walke. 1984. Present use of pest management practices in wheat, corn, and oats stored on the farm. Journal of Economic Entomology 77(2):784-788.

Tyler, P.S. and T.J. Binns. 1982. The influence of temperature on the susceptibility to eight organophosphorus insecticides of susceptible and resistant strains of Tribolium castaneum, Oryzaephilus surinamensis and Sitophilus granarius. Journal of Stored Products Research 18(1):13-19.
Wanas, E.M., G.A. Tantawy, A.E. Khamis, F.I. Moustafa, and M.I. Zeid. 1982. The toxicity of certain insecticides against the rice weevil Sitophilus oryzae (L). Research of Bulletin 500:1-10.

Watters, F.L., N.D.G. White, and D. Cote. 1983. Effect of temperature on toxicity and persistence of 3 pyrethroid insecticides applied to fir plywood for the control of the red flour beetle Tribolium castaneum (Coleoptera:Tenebrionidae). Journal of Economic Entomology 76 (1):11-16.

Wilkison, C.F. 1971. Insecticide synergists and their mode of action. Proceedings of the 2nd International IUPAC Congeries of Pesticide Chemistry 2:117-159.

Yamamoto, I. 1973. Pyrethroid insecticides and the synergists action and metabolism. Journal of Agricultural Science. Tokyo Nogyo Diagaku 17:273-313.

Zettler, J.L. 1991. Pesticide resistance in Tribolium castaneum and T. confusum (Coleoptera: Tenebrionidae) from flour mills in the United States. Journal of Economic Entomology 89(3):763-767.

Received December 2001.

Accepted March 2003. 